\title{
West African Palaeolithic history: New archaeological and chronostratigraphic data from the Falémé valley, eastern Senegal
}

\author{
Chevrier B. ${ }^{1,2}$, Rasse M. ${ }^{3}$, Lespez L. ${ }^{4}$, Tribolo $C^{5}{ }^{5}$, Hajdas I. ${ }^{6}$, Guardiola Fígols M. ${ }^{7,8}$, \\ Lebrun B. ${ }^{5}$, Leplongeon A. ${ }^{9}$, Camara A. ${ }^{10}$, Huysecom $E^{1}$.
}

${ }^{1}$ Laboratory Archaeology and Population in Africa, Department of Genetics and Evolution, Anthropology Unit, University of Geneva, Switzerland

${ }^{2}$ UMR 7041 CNRS ArScAn-AnTET, Nanterre, France

${ }^{3}$ Department of Geography, University of Rouen, France

${ }^{4}$ Department of Geography, University of Paris-Est Créteil, France

${ }^{5}$ Laboratory IRAMAT-CRP2A, CNRS, University of Bordeaux-Montaigne, France

${ }^{6}$ Laboratory of Ion Beam Physics, Eidgenössische Technische Hochschule - Zürich (ETH-Z), Switzerland

${ }^{7}$ Institut Català de Paleoecologia Humana i Evolució Social, Tarragona, Spain

${ }^{8}$ Àrea de Prehistòria Universitat Rovira i Virgili, Tarragona, Spain

${ }^{9}$ UMR 7194 CNRS, Department of Prehistory, Muséum National d'Histoire Naturelle, Paris, France

${ }^{10}$ Institut Fondamental d'Afrique Noire (IFAN), Dakar, Senegal

\section{Abstract}

For more than a century, Senegal has yielded abundant Palaeolithic finds, in particular on the Atlantic coast as well as in the Falémé Valley, but the lack of reliable and integrated chronocultural data has limited the possibilities of interpretation. These gaps were one of the main factors leading to the launch of a new research programme in the Falémé Valley (eastern Senegal). Its objective since 2012 has been to establish a new archaeological reference sequence in West Africa complementary to that of Ounjougou (Mali). Its more southerly location gave us the opportunity to obtain data to address the issue of human settlement and mobility in relation to changes in aridity and the position of the South-Saharan limit, along the north-south axis of the Falémé Valley.

Field survey enabled the identification of a very large number of sites, some in primary context, thus confirming the potential of the region. Geomorphological analysis and initial chronological results indicate relatively continuous and fairly complex deposition, with the alternation of fine-grained and coarser deposits, in particular for Marine Isotope Stages (MIS) 3 and 2. From an archaeological viewpoint, while artefacts attributed to very early periods (prior to isotope stages 4/5) were found in reworked contexts, several MIS 2, or even MIS 3 occupations up to the early Holocene (Ravin des Guêpiers, Fatandi, Toumboura, Missira), attracted significant attention. These sites provide complete, precise and reliable information. They contain assemblages using different techniques of production, which raise questions regarding cultural rhythms and changes, and show evidence of populations present during the 
hyperarid "Ogolian", during which the Ounjougou sequence has a major sedimentary and archaeological hiatus for this period.

Keywords: West Africa, Palaeolithic, Upper Pleistocene, Early Holocene, aridity

\section{Introduction}

Senegal occupies a particular place in the body of knowledge regarding the West African Palaeolithic, since, unlike other countries of this sub-region, a number of relatively large scientific investigations have been conducted there since the 1980s. In addition, if we include the research conducted in West Africa since the end of the $19^{\text {th }}$ century, Senegal stands out as the country with the highest number of archaeological sites per square kilometre, from the Palaeolithic to the historic period, reflecting the intensity of research that has been done (Huysecom et al., 1987, 2013). Syntheses have been published since the first part of the $20^{\text {th }}$ century (Laforgue, 1925; Corbeil et al., 1948) and research further increased with the development of specific organisations such as IFAN (Institut Français d'Afrique Noire, renamed the Institut Fondamental d'Afrique Noire), created in 1938 (Descamps, Descamps, 2010). For Palaeolithic research, the territory has not been investigated systematically, with "empty spaces in the central, eastern and southern regions [...] and a concentration in the western sector (Cape Verde) and along communication routes" (Camara, 1977). Several regions were the focus of interest, principally along the coast, around Dakar, Tiémassas, Rufisque, and the Gambia and Falémé Valleys.

\section{State of research}

In the Dakar region, abundant Palaeolithic data has been discovered, much of it in the 1940s and 1950s. However, most discoveries were found on the surface or in secondary position, as erosion and dismantling of Pleistocene formations were particularly intense in the western part of the country. Only a few sites or isolated artefacts were discovered in stratigraphic context, generally on the edges of the Atlantic beaches (notably Dakar-Champ de Tir), and are related to fossil beaches formed during the main transgressions during the Late Pleistocene (Hugot, 1967). The mixture of industries and the low frequencies of artefacts limit description of the lithic industries and prevent the formulation of clear definitions of regional technocomplexes (Baldé, 2010). Recurrent collections of bifacial tools, however, may indicate a very early human occupation that could be attributed to the Acheulean (Mauny, 1948). The discovery of bifacial tools at several sites attributed to an "evolved" or "recent" Palaeolithic formed the basis for the definition of a distinct facies, the Tiémassassian, after the 
eponymous site of Tiémassas (Dagan, 1956; Guillot and Descamps, 1969; Descamps and Descamps, 2010; see also Niang and Ndiaye, this volume). Several assemblages with archaic traits have also been discovered in different places along the coast (e.g., Lguer, Sebikothane, Cap Manuel) and were first attributed to the Sangoan, the Lupemban or other Central African facies such as the Kalinian (Davies, 1964), but some have ultimately been attributed to recent periods, notably the Neolithic (Richard, 1955, 1960). In the Gambia Valley, only three or four sites have been catalogued. In particular, assemblages with worked cobbles have been found, at Kédougou, Laminia and Samékouta, but are considered to be "contemporaneous with the Late Inchirian", i.e. in the second part of the Upper Pleistocene (Mauny, 1963; Barbey, Descamps, 1968). In Niokolo-Koba National Park, an assemblage with blades and endscrapers has been attributed to an Upper Pleistocene evolved Palaeolithic although without direct dating (Camara and Duboscq, 1984). In the Falémé Valley, while most discoveries were found on the surface, some assemblages are well situated stratigraphically and several geomorphological studies were conducted in the 1970s and 1980s by Camara and Duboscq (1984, 1987, 1990), associating a system of three terraces with the industries found, typologically attributed to the Lower, Middle and evolved Palaeolithic. Industries that appear archaic have also been found and contain choppers, bifaces and large flakes, such as at Karé and may be very old. Some Levallois elements associated with bifacial shaping at Sansandé could refine the attribution of this site to Final Acheulean. However, it lacks coherent assemblages in clear stratigraphic position. Several assemblages with blade production, endscrapers and/or foliate tools reflect an "evolved" Palaeolithic. No direct dates are available and the only chronological data comes from correlations between the staged terrace system and distant marine cores. According to this system, the first terrace would correspond to isotope stage $9(350-300 \mathrm{ka})$, the second between stages 7 and 5 (between 250 and $71 \mathrm{ka}$ ), with two independent episodes and finally, the most recent deposits to stages 3 and 2 (between 58 and $15 \mathrm{ka}$ ).

It is thus quite unreliable and somewhat rash to attempt to establish a precise chrono-cultural sequence for the Senegalese Palaeolithic given that the different cultural facies are generally still poorly defined, both in terms of typo-technology and chronostratigraphy. Diversity and a long history that seems to have developed from the Lower Palaeolithic to a "Later Stone Age" (LSA) and the Epipalaeolithic seem evident, but a re-evaluation of old data that can be interpreted and the discovery of new homogeneous, dateable and in situ sites in stratigraphic context remain crucial. 


\section{Importance of the Falémé Valley in the context of the West African Palaeolithic}

With this in mind, in order to obtain micro- and macro-regional chronostratigraphic data, a new programme of field survey, excavation and analysis within the framework of our research programme "Human settlement and palaeoenvironment in Africa" was begun in 2012. The aim of the programme is to establish a new chrono-cultural sequence in West Africa and address the relative lack of knowledge of the regional Palaeolithic in this area. In particular, the low number of reliable dates available has generally led archaeologists to ignore the available documentation and even to exclude this part of Africa from proposed models, despite the definite presence of ancient populations (e.g. McBrearty, Brooks, 2000; Garcea, 2012; Lombard, 2012). The proximity of the Sahara and the results obtained over the last fifteen years at Ounjougou in Mali (Soriano et al., 2010; Rasse et al., 2004, 2012; Tribolo et al., 2015) clearly highlight the potential in rebalancing our diachronic knowledge of the Palaeolithic through the development of a new West African study zone, using a multidisciplinary approach. Archaeology, geomorphology and geochronology thus form three inseparable poles for an overall and pertinent comprehension of human and natural phenomena during the Pleistocene: settlement, adaptation and behavioural evolution as a function of environmental and climatic change.

The choice of the Falémé Valley in eastern Senegal was made for several reasons (fig.1). First, research by A. Camara and B. Duboscq, cited above, clearly shows the wealth, technocultural diversity and especially the chronostratigraphic potential of this zone. Second, if the work at Ounjougou has enabled establishment of the first dated sequence in West Africa, it has also pointed out significant hiatuses, particularly during MIS 2, and the lack of information for the earliest periods, prior to MIS 5 (Soriano et al., 2010; Rasse et al., 2004, 2012; Tribolo et al., 2015). It is thus now crucial to complement the currently available data which, although it is of excellent quality for some cases, remains insufficient to develop a broader view in both space and time. Finally, the palaeoenvironmental argument is also essential. In effect, given Ounjougou's location in the now arid Sahelo-Sudanian belt, it seemed of particular importance to investigate a region further to the south, in a climatic zone which is today more humid than it has been at certain points in the past. Although recent research has demonstrated the north-south oscillation of the South-Saharan limit during the Late Pleistocene and Holocene (Collins et al., 2013), Dogon Country and the Falémé Valley, both by virtue of their geographic locations and their different geomorphological characteristics, are likely to have had distinct palaeoenvironments which were differentially affected by climatic change over time (see also Scerri et al., this volume). 
The aim of this paper is to present the archaeological results of four seasons of Palaeolithic field survey and excavations, complemented by geomorphological and chronological data, obtained from 2012 to 2015 between the villages of Alinguel and Missira, mainly on the left bank of the Falémé (fig.1). A preliminary comparison with the Ounjougou sequence and some questions of diachronic evolution are presented in the discussion.

\section{Preliminary geomorphological overview and chronological approach}

The Falémé Valley offers the possibility of partially resolving certain problems raised by the hiatuses in deposition, such as those observed in the Yamé Valley (Rasse et al., 2004; Lespez et al., 2008, 2011; Tribolo et al., 2015). The sedimentary record of the Falémé appears to be fairly continuous (at least during MIS 3 and 2), due to several factors. The Falémé river basin, a tributary of the Senegal River, is located in the southern part of the Sudanian zone. Precipitation is higher than in the Yamé watershed (> $1000 \mathrm{~mm}$ with means of $500 \mathrm{~mm}$ at Bandiagara) and this would also have been true during the driest periods of the Pleistocene. The Falémé flows northward: it was thus more regularly fed, even if its river basin is smaller compared to those of the neighbouring Gambia and Bafing Rivers. All three drain sandstone zones punctuated with intrusive Pre-Cambrian rocks from the Mandingue and Fouta Djallon Plateaux (Huysecom et al., 2011, 2012) and the topography plays a major role in the continuity of outflow from the south to the sahelian zone. Finally, and this does not appear to be a negligible factor, the geological conditions of the "Falemian narrow depression", a window of Mandingue sandstone bedrock exposed by erosion crossing from the south to the north of the Falémé River, likely favoured this south-north hydrological continuity (Michel, 1973). Paradoxically then, between the large rivers that would have undergone quite significant phases of flood flows during the Early Holocene (which would have eroded certain older formations) and the smaller hydrological networks poorly fed during dry periods with discontinuous records, the geomorphological situation of the Falémé is highly suitable for the analysis of relatively continuous sedimentary records. Its richness also suggests that the presence of water would have been regular in this valley (at least in the area surveyed and studied since 2011) and it is not impossible that its south-north direction was also the source of southern exchanges between climatic zones with different potentials.

The sedimentary sequence identified along the Falémé is complex. Several terrace levels with formations for which the geometry is sometimes difficult to understand have long been known (Michel, 1973; Camara, Duboscq, 1984, 1987, 1990). Without numerical dates or certainty 
regarding their transversal and longitudinal insertion in each sedimentary body, no interpretation has as yet been possible. Field surveys since 2011 and the first numerical dates now contribute to better understanding of their geometry.

Figure 2 shows the main sedimentary bodies known and lateral upstream-downstream relationships of the principal sections studied and presented here. Topographically, several generations of glacis and glacis terraces are observed. Terraces and glacis are here used here according to definitions of French terminology: glacis stands for a plane surface with a shallow slope where the bed rock has been covered by colluvial deposits successively reworked by sheet-wash (i.e. erosional glacis and accumulation glacis), while a terrace is a plane surface representing an alluvial accumulation. This geomorphological organisation explains the individualisation of the residual "buttes" (mounds) of Toumboura II, by gullying and alluvial erosion. A principal glacis and two well-individualised substitution glacis, the second in relation with the high terrace of the Falémé (HT) are found below the ferruginous duricrust glacis of the village of Missira (the "middle glacis" of Michel, 1969, 1973). Locally, another level of substitution is seen, related to the low or very low Holocene terrace (BT/TBT).

In terms of stratigraphy, we note the alternation of fine deposits, characterised by the reworking by colluvial and fluvial processes of fine particles found in the catchment (aeolian silts, flood silts, soil alteration, etc.; units "U": Uj, Us, Uc and Ug), and coarser deposits, generally channelized, rich in gravels, fine gravels and pisolites reworked from the nearby duricrusts (units "C"C: Cjs, Csc and Csup).

One charcoal and sediment samples for OSL were collected, mainly in units Us, Uc and Uj. The OSL dates are obtained on quartz grains extracted from sediment samples. Equivalent doses are determined on both multi and single grain analyses using single aliquot regenerative dose protocols. The dose rates are deduced primarily from both field and high resolution gamma spectrometry. (see Tribolo et al., 2015 for a similar methodological approach). Final age estimates are currently being resolved and will be published at a later stage. Here, we present the sites and assemblages in the current relative chronostratigraphic order, based on geomorphological data and, secondarily on preliminary chronological information.

\section{The presence of industries of archaic appearance}

Although most of the lithic industries discovered between 2012 and 2015 can be attributed to the Upper Pleistocene, evidence consistent with much older occupations is also found locally. Several localities have yielded artefacts, often large, that are technologically similar to 
production techniques considered "archaic", attributed elsewhere to the Lower Palaeolithic. Indicators of Acheulean assemblages have already been identified at Sansandé (or Sansanding) by A. Camara and B. Duboscq (1984) and our surveys have allowed us to identify bifacial shaping techniques in the coarse formations visible on the banks of the river. These artefacts are most often found associated with such formations, on the surface and in a state of preservation indicating transport and/or in non-stratigraphic position over the long term (artefacts with highly worn surfaces and ridges): at Alinguel, Ravin des Guêpiers, Sansandé, north of Toumboura, Missira, and even further north at Lalli, for example. In addition, the surveys along these coarse formations have generally led to the collection of archaic-appearing artefacts, often on the surface and in relatively large numbers among the dismantled cobbles: worked cobbles, spheroids, cores and flakes (sometimes Levallois) and bifacially shaped pieces (fig.3). No cleavers, common in the Acheulean in other African regions, have been found. The artefacts, found on the surface or in stratigraphic context, are nearly systematically made on coarse-grained materials such as sandstone and limestone-like rock.

More detailed examination of the naturally available sections led to the discovery of several stratified artefacts, although no archaeological level in primary position was observed. This is the case at Sansandé, with medium-sized flakes, less rolled than the other artefacts, in contact with slightly less coarse formations, in the upper part of the sections (none were collected). At the Ravin des Guêpiers ("Banks"), four artefacts were found in stratigraphic context, including two bifacial tools and a retouched flake (fig.3, $\mathrm{n}^{\circ} 4$ ). At Alinguel, a probable core and a possible hammerstone were found (fig.3, n5). Aat Missira ("Ravin sud" or South Ravine), several artefacts found at the base of a channel on the surface show varying surface states, more or less fresh, more or less rolled (fig. $3, \mathrm{n}^{\circ} 1$ to 3 ). These observations motivated a $1 \mathrm{~m}^{2}$ test excavation at the valley base, a few tens of $\mathrm{cm}$ deep, as well as the cleaning of a section on one of the banks. Only large sandstone and limestone-like flakes, sometimes laminar, as well as elements from quartz reduction (counting to be done), were found, without particular stratigraphic organisation. The idea of mixture is supported by the diversity in artefact surface conditions. These elements are similar in part to those collected at Missira I. The presence of a rolled and broken bifacial point should also be noted, isolated in a finegrained formation in the ravine south of Missira (fig.3, ${ }^{\circ} 8$ ). From a stylistic viewpoint, it could be attributed to the Middle Stone Age. Three OSL samples collected throughout the formation yielded a terminus ante quem (given the secondary context) of MIS 3 or 4 (further 
chronological precision is currently underway) for this point and indicates the existence of relatively early bifacial shaping in Falémé MSA.

The question of attaching the coarse formations to the same episodes of erosion and deposition is raised, particularly when variations are observed, with, for example, the presence at Alinguel of a formation indurated with small cobbles a few tens of $\mathrm{cm}$ above the coarse formation. Supplementary studies will be necessary to address this issue. Five samples for OSL dating were collected in the fine-grained formations (silty or sandy) overlying the coarse formations in the Ravin des Guêpiers and in Alinguel (respectively 2 and 3 samples). The dates obtained on the fine-grained sediments at Alinguel indicate that the rolled stratified artefacts are older than MIS 4/5 while those at Ravin des Guêpiers provide a terminus ante quem of MIS 2/3. We should therefore probably consider a relatively early age for these industries, perhaps earlier than $100 \mathrm{ka}$. In 2015, sediment was collected in three more samples in Sansandé. Analyses are pending. This situation is reminiscent of the assemblages with polyhedrals and spheroids found at Ounjougou (La Confluence, Ménié-Ménié) which, found in reworked position at the base of the sequence, are older than $150 \mathrm{ka}$ and similar to Lower Palaeolithic industries in North and East Africa (De Weyer, 2008; Soriano et al., 2010).

As with the discoveries made during the $20^{\text {th }}$ century in the Falémé Valley and the Dakar littoral, this archaic looking material remains unfortunately of little use in the context of detailed technological and chrono-cultural analyses. It can, however, inform us on the plausible presence of populations during periods earlier than stages $4 / 5$. We should remain cautious with respect to their chronological and cultural attribution in the absence of stratified occupations in primary context, a fortiori in these regions where the Palaeolithic is still poorly known. At Ounjougou, for example, the dating of assemblages that seemed at first to be attributable to the Lower Palaeolithic based on typology (Kokolo 2) have ultimately been shown to have a more recent age (MIS 5) (Soriano, 2003; Soriano et al., 2010). In Senegal, debates have existed on the attribution of certain assemblages to the Palaeolithic or the Neolithic (Mauny, 1963; Richard, 1955, 1960). The presence of well-preserved artefacts, with fresh edges, however, offers hope for the discovery of relatively undisturbed occupations that would contribute crucial elements to address these issues.

\section{Upper Pleistocene and early Holocene: assemblages in number and quality 6.1 Toumboura III}

In 2014, a survey in the formations south of the village of Toumboura allowed completion of the reconnaissance of occupations undergoing erosion. In particular, the discovery of an 
assemblage of shaping flakes associated with the fragment of a large bifacial piece, made of the same raw material (sandstone-quartzite), led to examination in 2014 and 2015 of the mound at the foot of which the material was found. A $1 \mathrm{~m}$ wide by $1.9 \mathrm{~m}$ high stratigraphic section was exposed on the southern face of the residual mound. Starting at the summit of the concentration of material, for a thickness of $60 \mathrm{~cm}$, thin spits were excavated to precisely locate a possible archaeological level. To the east, still on the southern face of the mound, a second section was more briefly exposed to verify the horizontal extension of the stratified material.

Sedimentary and geomorphological observations indicate that the entire mound belongs to the yellow unit (Uj). Some lithic artefacts were found in the upper part of the principal section but were rare. In contrast, the density of material is extremely high for about $40 \mathrm{~cm}$ in the lower part of the section, and even more marked over a thickness of $25 \mathrm{~cm}$. There thus appears to have been a relatively significant vertical dispersion. The eastern section yielded fewer artefacts and nearly no small ones. Taphonomic observations during excavation noted very oblique and vertical inclinations with different orientations. A high degree of breakage of the material is also noted. However, small debris less than $2 \mathrm{~cm}$ are present, the state of preservation of the artefacts themselves is excellent with many pieces with fresh edges and technological uniformity was noted during excavation. We thus conclude that this is an archaeological assemblage, a priori coherent, stratified, rapidly covered by fine-grained sediments but reworked, notably in depth, through post-depositional processes (especially trampling and bioturbation). The minor dispersion of material found on the surface and the low density of material in the eastern section suggest an overall spatially limited occupation. Three sediment samples for OSL dates were collected above, within and below the stratified assemblage and results are pending. However, the location of the yellow unit in the already known sequence indicates a chronological position earlier than the formations identified at Toumboura I, and thus likely at minimum earlier than $14 \mathrm{ka}$ cal BP. The dates already obtained at Toumboura II and the relative stratigraphic location of the two sites would thus indicate that the assemblage from Toumboura III would be attributed to MIS 2 or 3. Further precision is not yet available at present.

In terms of technology, these two excavations yielded more than 4000 artefacts, including around 500 greater than $2 \mathrm{~cm}$. These are mainly made of blue-gray sandstone-quartzite $(n=3642,90.6 \%)$ and, to a lesser degree, silexite $(n=288,7.2 \%)$, quartz $(n=44,1.1 \%)$ and other $(n=45,1.1 \%)$. Preliminary analysis of the material focused on the densest spits and the lithic assemblage that was concentrated in a thickness of around $40 \mathrm{~cm}(\mathrm{n}=435$ artefacts 
greater than $2 \mathrm{~cm}$ ). The rarity of cortical and natural surfaces suggests a partial reduction sequence with the first stages absent. The majority of the artefacts are broken $(n=346,79.5 \%)$, in part explained by the nature of the chaînes opératoires used (shaping) (fig.4). This limits the usefulness of metric analysis, particularly for the flakes that largely dominate the assemblage $(n=381,87.6 \%)$. They are generally short and wide with a fairly thin contour. Platforms are typically smooth and more than a third of the flakes, made on blue-gray sandstone-quartzite, show evidence of soft percussion associated with a frequently curved profile, indicating that they were produced during shaping chaînes opératoires (fig. $4, \mathrm{n}^{\circ} 6$ to 9). Some flakes may have been produced from debitage sequences, but more detailed study is necessary. Four cores have also been identified, three of which are small and made on silexite. These produced small flakes and bladelets. Such reduction sequences are thus clearly differentiated from those on sandstone-quartzite. The presence of a few points $(n=4)$, retouched or not, is an important characteristic. Some of the blanks are thick flakes with dihedral platforms (fig.4, $\mathrm{n}^{\circ} 3$ ). The lack of cores linked to the production of these pointed blanks could indicate offsite production, but retouch onsite may have been done. When these pointed blanks are retouched, covering unifacial or bifacial removals are common (fig.4, $\mathrm{n}^{\circ} 2$ ?). Such retouch is well associated with the shaping technique identified and could correspond both to the production of fairly large sandstone-quartzite tools (in particular, the bifacial piece collected in 2014 measures $9 \mathrm{~cm}$, but is broken in the mesial part) (fig. $4, \mathrm{n}^{\circ} 1$ ) and also to the production of small thin foliate tools on silexite $(1-2 \mathrm{~cm}$ maximum mesial width) and likely imported to the site (fig.4, $n^{\circ} 4-5$ ). Shaping accidents are common, and no finished tool from this production is whole. Sidescrapers, with lengths greater than $30 \mathrm{~mm}$, are also fairly common in the 27 retouched tools.

Toumboura III is currently the only site in the Falémé Valley to have yielded an industry with MSA-type bifacial shaping in stratigraphic context and this in a context where several technically different bifacial pieces have already been found on the surface. As a result, this assemblage serves as an essential reference in Senegal and more broadly in West Africa.

\subsection{Toumboura II}

After the discovery of abundant surface finds at the base of several residual mounds, more detailed examination of naturally available sections yielded several knapped and natural artefacts belonging to a highly localised archaeological layer on the north face of the northernmost mound (fig.5). Preliminary attribution of the sediments in which the artefacts were found to the yellow unit $(\mathrm{Uj})$ led to the exposure of a section to verify the presence of an 
occupation in primary context and to collect sediment samples for OSL dates. A large bioturbated zone required enlarging this section to $1.80 \mathrm{~m}$. The recovery of well-stratified archaeological material led to more extensive excavations of slightly more than $2 \mathrm{~m}^{2}$ (squares A4 to B5) (fig.5).

We were able to identify a lithic assemblage deposited and preserved in a thin layer of around $10 \mathrm{~cm}$. The freshness of the artefacts, the stratigraphic information and the low number of marked oblique or vertical inclinations indicate a nearly undisturbed occupation except in the central zone which was entirely affected by bioturbation, from which the artefacts were emptied and found several tens of $\mathrm{cm}$ lower. The level has a slight slope to the east. Two samples for OSL dates were collected in the western part: one directly above the layer, the other about $30 \mathrm{~cm}$ below. The preliminary results allow attribution of the occupation to MIS 2. We are currently in the process of obtaining more precise dates.

A total of 425 pieces with a length greater than $2 \mathrm{~cm}$ was recorded in three dimensions and collected: 339 are artefacts, while the others are natural ( $n=86$ or $20.2 \%)$. The fine grain of the deposits raises the question of importation by humans of these natural pieces. Preliminary analysis of the artefacts shows the use of very simple reduction techniques. Detailed raw material determination is in progress but, in a preliminary view, on a sample of 140 pieces, the artefacts are mainly made of limestone/chert ( 100 pieces and 70\%), sandstone $(\sim 30$ pieces and 25\%), and sometimes of quartz, quartzite and silexite (less than 4 pieces and 3\%). The limestone blocks used are plaquettes a few $\mathrm{cm}$ thick (fig.6, $\mathrm{n}^{\circ} 1-2$ ). The chaînes opératoires consist of simple debitage sequences, limited to the removal of a few flakes in series (fig.6, ${ }^{\circ} 2-3$ ). A more detailed analysis to describe the volumes and intended products remains to be done, but the low number of cores $(n=4,1.2 \%)$ and the absence of cores that were used to produce the larger flakes will limit reconstruction. In terms of tools, the archaic aspect is obvious with the production of sidescrapers, denticulates and notches in fairly large numbers (at least 46 retouched tools or $10.8 \%$ ) (fig.6, $\mathrm{n}^{\circ} 4$ to 6 ). Some traces appear to be usewear or post-depositional. At first view, and despite some relative differences in the proportions of raw materials used and the types and selection of blanks, the techno-cultural and chronological similarities with the assemblages from the Ravin des Guêpiers, excavated in 2012 and 2013 is clear.

\subsection{Ravin des Guêpiers}

This site, the first to have been tested and investigated in 2012 and again in 2013, is located north of the village of Goundafa. After many artefacts were found on the surface at the base 
of small, highly eroded mounds and crests, an initial test excavation was conducted at the top of a crest. Archaeological material appeared not far from the surface, but the area excavated was small (115 $\mathrm{cm}$ by $45 \mathrm{~cm}$ ). In 2013, four sectors were tested at different depths, the first (Sector I) corresponding to the extension of the 2012 test pit along the adjacent crests (for a total of $3 \mathrm{~m}$ long by $40 \mathrm{~cm}$ wide) to complete the archaeological corpus (fig.7). Several stratigraphic sections were added to this, the principal section (South section) measuring $4 \mathrm{~m}$ in height (fig.2).

Relatively dense lithic artefacts were recovered in Sector I. They are concentrated in a fairly thin archaeological layer, already quite dismantled (fig.7), and show excellent preservation and few marked oblique or vertical inclinations. The presence of many small elements supports an undisturbed occupation, with a slight slope to the south-west. The other sectors either yielded materials without an evident archaeological layer (due to significant bioturbation) or lithics associated with ceramics, likely in Holocene deposits. The South section as well as two other more limited sections allowed the recovery of a few lithic artefacts, more concentrated at certain depths but without localised stratification observed.

Seven sediment samples were collected for OSL dates: six throughout the South section and one a few ten or so cm below the archaeological layer in Sector I. Apart from the deepest sample in the South section, preliminary dates suggest all samples belong to MIS 2 (further chronological dating is currently underway). Stratigraphic correlations and depths support an attribution of the archaeological layer to the start or during the first millennia of the hyperarid Ogolian.

From the archaeological layer, 73 pieces were measured in three dimensions, regardless of size: 40 pieces are less than $2 \mathrm{~cm}(54.8 \%)$. The assemblage is thus limited but remains informative. The surface material collected at the base of the crests provides additional elements. The raw materials utilised are typically quartz $(n=47,64.4 \%)$ and siliceous limestone ( $n=18,24.7 \%)$ (fig.8). A few artefacts were made on sandstone, silexite, and flint. Quartz was collected as small cobbles while the limestone was in the form of thin plaquettes, possibly broken by an orthogonal blow to the largest surfaces (fig. $8, \mathrm{n}^{\circ} 1$ ). The assemblage is dominated by flakes $(n=38,52.1 \%)$ and knapping debris $(n=20,27.4 \%)$ and at least three cores are present $(4.1 \%)$. Some elements are natural. Flake platforms vary in size, but are commonly smooth, natural or the result of a single removal. Siret fractures are fairly common. The use of hard stone percussion is thus clear. The dorsal faces do not show preferential organisation. They indicate different reduction patterns and are cortical, semi-cortical or noncortical, with one or more unipolar or centripetal removals. Débordant flakes are present and 
underline the simple management of convexities. Debitage structures are thus not elaborate and are focused on the limited creation of striking platforms and the removals of a few blanks in series (fig.8, $\mathrm{n}^{\circ} 1-2$ ). The intended flakes are rectangular or triangular and offset, 3-4 cm

(fig.8, $\mathrm{n}^{\circ} 3,5$ to 11 ), although a few are larger $\left(>6 \mathrm{~cm}\right.$ ) (fig.8, $\left.\mathrm{n}^{\circ} 4\right)$. The hypothesis of importation of part of the material is thus advanced, but no raw material sources or large cores were identified nearby. The tools include unretouched artefacts, such as the offset triangular flakes, as well as four pieces with direct or inverse retouch (5.4\%) to form sidescrapers, denticulates and convergent pieces (fig.8, $\mathrm{n}^{\circ} 3,7-8,10-11$ ). The surface material confirms these patterns, both with respect to the selection of raw materials and the reduction structures. Despite an attribution to a recent period (stage 2), the archaic and simple aspect of lithic production and the tools is evident, as at Toumboura II.

\subsection{Missira I}

At Missira I, the recognition of thin sedimentary mounds covered with pisolites led to more detailed examination of these formations. Their low height indicates their anteriority to the stratified unit (Us): they correspond to one of the earliest deposits accessible, linked to the upper part of the sequence. Further, the archaeological material seems to be found in a subhorizontal layer at the end of a tongue of sediments.

A limited $1 \mathrm{~m}^{2}$ test pit was dug in this deposit, to a depth of $1 \mathrm{~m}$ (fig.9). In addition, to the north, a $2.30 \mathrm{~m}$ high section $80-130 \mathrm{~cm}$ wide was exposed, starting at the base of the stratified unit, and a $3 \mathrm{~m}$ trench excavated (fig.9).

In the test pit, two horizons could be identified: the upper horizon (Cjs) is $20-30 \mathrm{~cm}$ thick with lithic artefacts and the lower horizon (Uj) is archaeologically sterile (fig.9). A few pieces were collected from the section but remain rare. The material from the test pit was not structured in fine archaeological layers and does not correspond to a particular gravelly or silty lens. In addition, the surfaces vary - fresh, worn, altered by physical-chemical action - and suggest a disturbed archaeological assemblage but overall uniform from a technological viewpoint.

In 2015, five sediment samples were collected throughout the North section for OSL dates (analyses in progress). The intermediary position of $\mathrm{Cj}$ s, between $\mathrm{Uj}$ (in which Toumboura II and III are located) and Us (fig.9), and the reworked position of the material would support a terminus ante quem for MIS 2.

Typo-technical elements identified in preliminary analysis suggest two technologically different assemblages. The first contains large flakes of varying shape, at least $50 \mathrm{~mm}$ long, made on limestone-like raw material or sandstone (fig.10, $\mathrm{n}^{\circ} 1$ ). Their production appears to 
be based on simple concepts and hard percussion. One piece could, however, reflect more advanced management of convexities. No cores related to these blanks were found. A more detailed analysis is in progress to describe these artefacts. Several bifacial pieces, mostly plano-convex and made on the same types of raw material, were surface finds on and around these deposits. We can neither exclude nor support the hypothesis of a possible technological link and the discovery of this type of artefact in stratigraphic context is essential to discuss the relationships between knapped blanks from the test pit and the shaped pieces from the surface. The second assemblage is composed of quartz artefacts from cobbles or cobble fragments, some of which have plausible traces indicating bipolar on anvil percussion (fig.10, $\mathrm{n}^{\circ} 2-3$ ). It is possible that notches were created on some pieces, but more detailed examination is needed. This association is reminiscent of the artefacts found in the test excavation in the Ravin sud of Missira, but it is still too early to propose technological and cultural connections.

\subsection{Fatandi $V$}

The site of Fatandi V was identified during the 2012 surveys. It is located between the villages of Alinguel and Goundafa near the banks of the Falémé. Several fairly individualised extremely rich lithic concentrations are visible on the eroded surface (fig.11), with a gradual slope to the south-west. Three operations were conducted at the site. In 2012, we documented the southernmost concentration ("Amas 1" sector), which features a high density of surface artefacts. The study of 30 lithic pieces was done, enabling identification of the association of different reduction concepts and highlighting several questions concerning the integrity of the concentration. In 2013, a detailed photographic map and recovery of material by $1 / 16 \mathrm{~m}^{2}$ $(25 \times 25 \mathrm{~cm}$ sub-squares) was done in this sector in order to evaluate the distribution of the surface material (fig.11). A deep test pit for OSL dating samples yielded complementary data. In addition, the excavation of two north-south oriented trenches ("North trench" and "South trench"), 15 and $16 \mathrm{~m}$ long respectively, in the continuity from one to the other, and $50 \mathrm{~cm}$ wide, was motivated by the dismantling, due to erosion, of a large lithic concentration ("Amas 2" sector), about ten m north of the Amas 1 sector (fig.12). These trenches allowed testing the hypothesis of the existence of an archaeological layer in primary context. They were excavated to depth of $10-40 \mathrm{~cm}$ and in several areas deeper test pits were dug to $1.20 \mathrm{~m}$ to obtain more complete stratigraphic and archaeological data. Additionally, a more extensive zone of $5 \mathrm{~m}^{2}$ was excavated, including within it the entire lithic concentration (N-8, N-9 and N-10 extensions) (fig.12). Finally, after the discovery of material in the northern part of the North trench, an extension (called "North square") was opened to collect sediment samples 
for OSL dating. However, the appearance of a very rich concentration required work in this sector to be suspended until the next season. In 2014, the North square was completely excavated $\left(\sim 1.5 \mathrm{~m}^{2}\right)$ (fig.12) as well as the extension of the North trench with the testing of several sections on $10 \mathrm{~m}$. The discovery of a small lithic concentration led to a $2 \mathrm{~m}^{2}$ extension east of the NExt-4 section.

The excavation of the South trench yielded very little material in the deposits; the occupation(s) of this part of the site had thus been almost entirely eroded. Study of the distribution of the movement of artefacts less than and greater than $2 \mathrm{~cm}$ in the Amas 1 sector between the 2012 and 2013 seasons indicates that the smallest artefacts were transported along the slope, most likely by precipitation. The largest artefacts show little movement in the middle of the concentration but clearly more on the periphery (Huysecom et al., 2014). Trampling by animals and humans is the probable cause of such displacements. We can thus propose that the Amas 1 sector, although dismantled and partially disturbed, has preserved its general original structure. The freshness of the artefacts and the uniformity of the raw material (blue-green jaspoid silexite) suggest a relatively good degree of integrity for the concentration. A few highly patinated pieces may be intrusive. The deep test pit in this sector contained no artefacts below the concentration. Conversely, the North trench and its extension yielded stratified material: a total of 303 artefacts of all sizes distributed in several zones were identified and coordinates recorded. Their stratigraphic position is overall similar to that of the lithic assemblages found in the extensions of zones N-8 to N-10 (Amas 2 sector) and in the North square. For the first, the coordinates of 471 artefacts greater than $2 \mathrm{~cm}$ were recorded (to which those collected on the surface can be added) and define a highly localised layer (fig.12). Similarly, for the North square, an extremely dense and undisturbed concentration $80-100 \mathrm{~cm}$ in diameter yielded 729 artefacts greater than $2 \mathrm{~cm}$ (fig.12). Additionally, in the extension of sector NExt-4, 21 artefacts have the same stratigraphic position. The different deep test pits yielded no underlying artefacts. The systematic use of silexite, the freshness of the artefacts, the extremely high density of small debris and the low number of marked oblique or vertical inclinations clearly support the hypothesis of a single archaeological layer, completely eroded in the southern part, partially dismantled in the Amas 2 sector, but entirely in situ in the northern part. It is sub-horizontal with a slight general slope of $1 \%$ towards the north, opposite to the slope of the modern surface. In some zones, the slope is locally more marked, up to $3 \%$. As a result, the layer appears to be composed of several contemporaneous or penecontemporaneous lithic concentrations separated by zones of lesser density. 
Several sediment samples were planned for OSL dating. In 2013, two samples were collected at 30 and $70 \mathrm{~cm}$ below the archaeological layer in the Amas 2 sector and two others at 30 and $70 \mathrm{~cm}$ below the surface in the Amas 1 sector. These yielded a terminus post quem of the end of the Pleistocene, with further chronological refinements in preparation. Five new samples were collected in 2014 in the North square just above the layer and $30 \mathrm{~cm}$ below it, and in the NExt-4 sector, $30 \mathrm{~cm}$ above, at the occupation and $30 \mathrm{~cm}$ below it. Detailed analyses are in progress and should allow discussion of a chronological position at the end of the Pleistocene or early Holocene.

With respect the stratified artefacts, all are made on blue-green jaspoid silexite except for two. Procurement was made of plaquettes with many parallel and orthogonal fissures such that they could be divided into other, thinner plaquettes (fig.13, $\mathrm{n}^{\circ} 1-2$ ). Despite the fine grain of the raw material, the quality of knapping is directly affected by these fissures, limiting the management of large blocks and more complex preparation. However, different reduction techniques are associated within this assemblage. The production of wide bladelets is one of the key characteristics of Fatandi V (fig.13; fig.14, $\mathrm{n}^{\circ} 1$ to $10 \mathrm{~d}$ ): these were obtained by unipolar parallel (or slightly convergent) exploitation on slightly convex or flat surfaces near the edge of a plaquette (fig.13, $\mathrm{n}^{\circ} 1-2$ ). Recurrent production is often limited to short series of removals without particular preparation except for the creation of a striking platform across the thickness of the block. However, prismatic cores were also found with the preparation of a frontal crest guiding the first bladelet and the creation of a striking platform (fig.13, $\mathrm{n}^{\circ} 4-5$ ). Production remains frontal. Finally, cores similar to the Levallois concept were also found; these were used to produce blanks, lamellar or not, from a flaking surface a priori selected in relation to a striking platform and composed of lateral and potentially distal convexities (fig.13, $n^{\circ} 3,6$ to 8 ). The latter may be prepared but are very often flat natural surfaces. The detachment of knapped blanks was done parallel to the plane of intersection of the two surfaces, in some cases slightly obliquely. Some flakes could be associated with this reduction technique but remain rare. The low degree of preparation for these cores, approximate knapping behaviours (as described above), and the low number of Levallois technical pieces nonetheless raise some doubt as to real mastery of the Levallois debitage: are they really Levallois cores or ways of knapping which are morphologically close to Levallois? Technological analysis is in progress to contribute more detailed information. Significant natural breakage of the blocks (and maybe their selection) could be an explanatory element. Bladelet cores could be reused as flake cores in the last steps of production and, because of the exploitation of wide surfaces, get finally close to the Levallois-like cores previously 
described (fig. 13, n6-7?). A few small blocks also show simple or opportunistic production of one or more short flakes. The presence in the Amas 1 sector (and thus on the surface) of cores with a shallow ridge obtained by the meeting of two natural flat surfaces should be noted (Huysecom et al., 2013). Preparation is limited to the creation of a striking platform by one or more removals orthogonal to this ridge. No evidence of maintenance is visible and production is limited to a few fairly wide and convergent bladelets with hinged fractures leading to discard of the block.

Retouched pieces are very rare and unretouched bladelets show no macrowear evidence of use. The main behaviour is that of abrupt, linear or denticulate retouch on the edges of small fragments of thin natural plaquettes (fig.14, $\mathrm{n}^{\circ} 11$ ). In some cases, the worn aspect of the scars seems to indicate a transformative role of these zones. Moreover, two pieces made on a different fine-grained and siliceous raw material, whitish or faintly green and veined, were also found: these are two medium-sized fairly thick segments (3-4 cm) (fig.14, $\left.\mathrm{n}^{\circ} 12-13\right)$. They are technologically and functionally similar with a convex edge retouched along the entire length opposite an unretouched rectilinear edge. They were clearly imported to the site. While no segments of blue-green jaspoid silexite were found in stratigraphic context, several were collected from the surface. Their morpho-technical criteria are slightly different (points, discontinuous or partial retouch, etc.) but can be readily included in the assemblage. The question of whether bladelets were transformed into segments and backed pieces is thus raised. It had been previously suggested that this was the case for the assemblage from the site of Fanfannyégèné (Mali), where the preferred technique was the Krukowski microburin technique (Huysecom, 1990). However, this site is younger than Fatandi V (2680 \pm 120 uncal. BP). At Fatandi V, the absence of technical elements allowing understanding of the chaine opératoire for the production of the two segments found as yet prevents interpretation of the technique for bladelet fragmentation.

\subsection{Toumboura I}

The presence of abundant surface artefacts along the gullies of the principal glacis at Toumboura, particularly small segments, led us to survey these zones in detail in 2014. At different places, a sub-horizontal layer appeared in stratigraphic context across several tens of meters (fig.15, photo 3). More specifically, at Toumboura I, this material and the presence of a coarse channel in the middle of a fine-grained sedimentary sequence made this site of particular interest and led to the excavation of a section more than $5.50 \mathrm{~m}$ high, from the 
surface of the principal glacis to the deepest deposits accessible naturally. Its width was limited, from $1 \mathrm{~m}$ to $50 \mathrm{~cm}$ in the upper part for technical reasons (fig.15).

After the approximate measurement of the depth from the archaeological layer(s) on the surface $(-170$ to $-220 \mathrm{~cm}$ below the top of the glacis), we also opted to excavate $10-\mathrm{cm}$ thick spits between depths of -150 and $-250 \mathrm{~cm}$ in order to identify the number of occupations and situate them precisely. All of the sediments from these spits was collected and water sieved to obtain all of the archaeological pieces (without size limits).

The results indicate a very clear concentration of over 1200 lithic artefacts in the -160/-170 $\mathrm{cm}$ spit. In the overlying and underlying spits, material is also present but in much lower frequencies (a few dozen pieces in the $-150 /-160 \mathrm{~cm}$ spit and less than 150 artefacts in the underlying spits to $-250 \mathrm{~cm}$ ) (fig.15). This distribution of material is interpreted as result of bioturbation within a single archaeological layer, even though the material at Toumboura I is small in size. The freshness of the artefacts and the good stratigraphic location of the occupation allow us to propose a primary context for the site, within the gray unit (Ug).

Nine OSL samples were collected throughout the section. One of these is found at the bottom of the archaeological layer. Initial analyses indicate that all of the units in the section belong to MIS 2, with the most recent belonging to the beginning of the Holocene. This result is consistent with a date obtained on charcoal collected at an approximate depth of -220 to -230 $\mathrm{cm}$ (around $60 \mathrm{~cm}$ below the archaeological layer) and a few tens of $\mathrm{cm}$ to the side of the principal section during section cleaning. However we acknowledge caution with regards to the sample location and the possibility of vertical movement, which places the Uc/Ug transition around $14 \mathrm{ka}$ cal BP (12114 \pm 59 uncal BP / ETH-55080) (fig. 16). While awaiting more precise results, we can at present attribute the occupation of Toumboura I to the end of the Pleistocene or early Holocene.

Preliminary typo-technical observations suggest the exploitation of small blocks of blue-green jaspoid silexite, often with the remains of alluvial cortex (fig. $17, \mathrm{n}^{\circ} 1$ to 6 ; fig.18). Siliceous rock (chemically altered, making the surface close to limestone) and sandstone were also used, both clearly comprising larger blocks (fig.17, $\mathrm{n}^{\circ} 7$ to 11 ). The small blocks of silexite show simple debitage in short unipolar, bipolar and orthogonal series. Preparation, which is not systematic, is limited to the creation of a striking platform (fig. $17, \mathrm{n}^{\circ} 1$ to 6 ). The intended blanks are small flakes, débordant or not, and bladelets. These were then modified into microliths by abrupt complete or partial retouch of one of the edges to obtain segments and points, which are found in large numbers (fig.18). Their length is rarely greater than $2 \mathrm{~cm}$, but segments are larger, between 2 and $3 \mathrm{~cm}$ long. Some of them show bifacial accidental scars 
on the cutting edge, which suggests transverse impact or strong use (fig.18, ${ }^{\circ} 9-10$ ). This material is associated with larger flakes (several $\mathrm{cm}$ ) on altered siliceous rock and sandstone, produced by internal hard percussion. Their platforms can be smooth or facetted and hinges are sometimes observed (fig. $17, \mathrm{n}^{\circ} 7$ to 11 ). They are not associated with any cores present in the assemblage and the organisation of the dorsal faces does not currently allow interpretation of the reduction strategy. No ceramics were found.

\section{Preliminary overview and micro- and macro-regional perspectives}

These seasons of survey and excavations in the Falémé Valley, the first in thirty years, confirm not only the exceptional archaeological potential of the eastern Senegal zone, but also suggests that it will be possible to establish a new reference sequence in West Africa. The importance of this region is due both to the number of sites discovered and the intra-site data available. Indeed, although the number of artefacts can be highly variable (from dozens to several thousand), the lithic material is quite regularly in an excellent state of preservation, thus allowing detailed analyses. This situation is linked to the varied preservation contexts, ranging from surface assemblages (potentially mixed) to undisturbed in situ occupations, as at Fatandi V. Mainly found in fine-grained silty deposits, such evidence can also be found in sandy or gravelly deposits or in much coarser formations (for the latter, in secondary position and rolled). What we have then are varied situations, revealing complex archaeological and sedimentary histories.

Chronostratigraphically, the preliminary estimations suggest an early human presence (rolled artefacts earlier than stages 4/5) and place stratigraphic units Us, Uc and Uj (upper part) in MIS 2 or, for the base of the sequences of the Ravin des Guêpiers and Missira (and maybe for Uj lower part), possibly in MIS 3. The period between 30,000 and 5,000 BP is therefore most likely to be very well-represented. This is extremely important since no other sites are presently being studied in West Africa that would clarify the Pleistocene-Holocene transition: the Yamé Valley (Dogon Country, Mali) has a major sedimentary hiatus for this chronological period (Robert et al., 2003; Soriano et al., 2010).

From an archaeological viewpoint, very different production techniques have been identified, documented and collected. In a simplified techno-cultural framework, we would propose attributions ranging from the Early Stone Age to the Later Stone Age. The industries are quite different from one another: "archaic" pieces, worked cobbles, bifacial shaping, Levallois reduction, cores and tools of "rabot" type, foliate pieces, simple reduction strategies and tools, bipolar on anvil reduction, bladelet production, segments and microliths. These techniques 
highlight skills changing through time but for which the rhythm remains to be more clearly documented. It appears, however, that some of these assemblages, composed notably of bifacial pieces, belong to very early periods, prior to MIS 4 and 5, thus confirming a significant temporal depth as already identified by Camara and Duboscq $(1984,1990)$, which remains to be evaluated.

The most abundant and startling information appears to date to the Upper Pleistocene. Prior to obtaining the preliminary OSL results, the sites found at Toumboura, Missira, the Ravin des Guêpiers and Fatandi were considered to be distributed throughout a relatively long range of time (e.g. MIS 5 to 2). However, it is now undeniable that most of these are found in MIS 2. Some of these sites are even dated to the hyperarid Ogolian episode (20-15 ka BP) and this within thick sedimentary deposits that are generally difficult to identify in the SaheloSudanian belt. These results are even more surprising since the reduction strategies are quite diverse (bifacial shaping, foliate pieces, simple reduction, archaic-appearing tools, potentially bladelet productions and segments), implying major variations in technicity over the very short duration of a few millennia. The chronological placement of Ravin des Guêpiers during the Ogolian should be particularly noted, as it raises the question of a potential loss of technical knowledge during an intensely arid climatic episode. Are these two phenomena directly correlated and if so, what were the social mechanisms at work (e.g., hypermobility, isolation, etc.)? Or is this situation only the result of our current, biased, state of knowledge and should we conclude to a more complex scenario? Analyses of OSL samples in progress will give us some important information, but more field and technological data is necessary.

We also note in the Fatandi $\mathrm{V}$ assemblage the presence of two large segments. The low number of segments limits interpretations. However, they were clearly produced in association with bladelet production at the end of the Pleistocene/early Holocene, making them an excellent chrono-cultural marker and thus rare, concerning the production of backed pieces in West Africa. Questions naturally follow with respect to the techno-evolutionary link between the simple reduction strategies at Ravin des Guêpiers and Toumboura II and the more complex strategies and the production of the first segments at Fatandi V and Toumboura I. How can such technological differences be explained at the end of MIS 2? Due to the great differences for each characteristic of the assemblages (raw materials, procurement, production, blanks and toolkit), it seems difficult to hypothesise that such differences merely represent separate activities by the same groups. Instead, some sort of cultural, social or environmental break or leap may have occurred. However, the currently available archaeological resolution may not allow us to observe a more gradual phenomenon. 
Finally, we also note the question of a continuous or discontinuous phenomenon of bifacial shaping of MSA type. The diversity in bifacial pieces collected on the surface, compared with the artefacts from Toumboura III (MIS 3 or 2) and Missira (piece in secondary position prior to MIS 3 or 4), does not support the idea of a single phenomenon. The repetition of expressions of bifacial shaping has already been recognised at Ounjougou in Mali (Soriano et $a l ., 2010)$. While it is still too early to propose an interpretation for the Falémé Valley, the initial data may indicate a similar model.

In summary, these results constitute a significant advance of knowledge of the Palaeolithic in Senegal and more broadly in West Africa. More specifically, the documentation of lithic assemblages attributed to MIS 2 is presently unique. At Ounjougou, the sequence, considered the most complete for the West African Palaeolithic, shows an occupation hiatus precisely during this period, likely due to extreme environmental conditions (Soriano et al., 2010; Rasse et al., 2004, 2012; Tribolo et al., 2015). With the sedimentary and archaeological record of the Falémé Valley, in parallel with the possibility of discussing early occupations, we also have the opportunity to begin to fill in major chrono-cultural gaps in the West African Pleistocene. The combination of data from research at Ounjougou and the Falémé Valley, together with other investigations will thus enable us to continue to develop an overall view of Pleistocene settlement in this region.

\section{Acknowledgments}

We would like to thank several institutions and individuals for their participation or support for the project: the Swiss National Science Foundation for its support for years (request $\mathrm{n}^{\circ}$ 101212-124657), the SLSA Foundation for its additional funding, the Faculty of Science of the University of Geneva for the AFRI budget line, the French Ministry of Foreign Affairs, the University of Bordeaux-Montaigne, the Swiss Embassy in Senegal, the Fundamental Institute of Black Africa (IFAN) at the University Cheikh Anta Diop (UCAD), especially Hamady Bocoum, the administrative and technical staff of the Anthropology Unit of the Department of Genetics and Evolution (University of Geneva), the workers from Toumboura, Alinguel, Goundafa and Missira (Senegal), the team of Dimmbal (Mali), the African and European students. We thank James Blinkhorn, Eleanor Scerri, Anne Delagnes and Huw Groucutt for inviting us to present the first results of our project in Bordeaux and Becky Miller for the translation of this paper.

\section{Captions}


Figure 1: Map of villages and archaeological sites surveyed between 2012 and 2015 in the Falémé Valley. 1: state border; 2: main town; 3: village and studied site; 4: isolated archaeological site.

Figure 2: Location of the studied sites in the recent formations of the Falémé Valley (drawing M. Rasse). OSL samples in Fatandi V ( $\mathrm{N}=9$ for the archaeological layer) are too numerous to be represented.

Figure 3: Lithics collected in Missira - Ravin sud (1 to 3, 8), the Ravin des Guêpiers (4), Alinguel (5) and Lalli (6-7). 1-2, 4: bifacial pieces; 3: Levallois core; 5: tool-core; 6-7: laminar flakes; 8: bifacial point. 1 to 3, 6-7: surface collect; 4-5, 8: stratified lithics (photos B. Chevrier).

Figure 4. Toumboura III, lithic artefacts. 1-2: bifacial pieces; 3: retouched point on triangular flake; 4-5: small foliates; 6 to 9: shaping flakes. 1-7: surface collect; 2 to 6, 8-9: stratified lithics (photos and drawings B. Chevrier and A. Leplongeon).

Figure 5: Toumboura II, planimetric and stratigraphic distribution of lithic pieces. The grey area is disturbed by bioturbation.

Figure 6: Toumboura II, lithic artefacts. 1: tool-core; 2-3: flake cores; 4-5: retouched flakes; 6: retouched natural blank (photos B. Chevrier).

Figure 7: Ravin des Guêpiers, planimetric and stratigraphic distribution of lithic pieces. The excavation was realized at the top of an eroded crest.

Figure 8: Ravin des Guêpiers, lithic artefacts. 1-2: cores; 3, 5-6, 9: flakes; 4, 7-8, 10-11: retouched flakes. 1 to 7: limestone; 8 to 11: quartz. 1, 3 to 11: stratified artefacts; 2: surface collect (drawings B. Chevrier).

Figure 9: Missira I, stratigraphy, north section and test pit (photos and drawings B. Chevrier).

Figure 10: Missira I, lithic artefacts. 1: flake; 2-3: quartz pebbles with probable evidence of bipolar percussion on anvil (photos B. Chevrier). 
Figure 11: Fatandi V, general view of "Amas 1" sector during collecting (photo B. Chevrier).

Figure 12: Fatandi V, map of north trench and extensions (on the left), drawing of the "north square" concentration (above), planimetric and stratigraphic distribution of lithic pieces from $\mathrm{N}-8$ to $\mathrm{N}-10$ extensions (below).

Figure 13: Fatandi V, lithic artefacts. 1 to 4, 7: bladelet cores; 5-8: refitted bladelets; 6: possible Levallois core (surface collect) (photo and drawings B. Chevrier).

Figure 14: Fatandi V, lithic artefacts. 1 to 10d: bladelets; 9c: refitting of 9a and 9b bladelets; 10d: refitting of 10a to 10c bladelets; 11: retouched natural blank; 12-13: segments (drawings B. Chevrier).

Figure 15: Toumboura I, section and stratigraphic distribution of lithic pieces (photos 1-2 and drawing). Photo 3: lithic artefacts in archaeological level (white arrow) appearing on surface (photos B. Chevrier, drawing D. Glauser).

Figure 16: Calibrated radiocarbon age of charcoal sample. Prior to AMS analysis sample of charcoal was treated using acid-base-acid treatment (Hajdas, 2008). The remaining amount of carbon (after combustion of charcoal) was $0.350 \mathrm{mg}$. Picture is of the original material (prior to treatment).

Figure 17: Toumboura I, lithic artefacts. 1 to 6: flake and bladelet cores; 7 to 11: mediumsized flakes. 1 to 3, 7 to 11: stratified artefacts; 4 to 6: surface collect (photos B. Chevrier).

Figure 18: Toumboura I, lithic artefacts: points and segments. 1-2, 7, 9-10: stratified artefacts; 3 to 6, 8: surface collect. The thick line highlights the retouched back, the thin line shows the cutting active edge (photos B. Chevrier).

\section{References}


Baldé, D., 2010. Le Paléolithique de Sébikotane: nouvelles perspectives sur le contexte stratigraphique et typologique à partir du site de Sébi-Discours. 13rd PANAF Congress Abstracts. IFAN-Université Cheikh Anta Diop, Dakar, p. 63.

Barbey, C., Descamps, C. 1968. À propos de galets aménagés de la moyenne Gambie. Bulletin de l'Association Sénégalaise pour l'Etude du Quaternaire de l'Ouest Africain, 18, 1922.

Camara, A., 1977. Le Néolithique du cap Manuel (Dakar). Faculté des lettres et sciences humaines. Master Thesis, Université Cheikh Anta Diop, Dakar.

Camara, A., Duboscq, B., 1984. Le gisement préhistorique de Sansandé, basse vallée de la Falémé, Sénégal. Approche typologique et stratigraphique. L’Anthropologie, 88 (3), 377-402.

Camara, A., Duboscq, B., 1987. Contexte chronostratigraphique des outillages du Paléolithique évolué dans l'Est du Sénégal. L'Anthropologie, 91 (2), 511-520.

Camara, A., Duboscq, B., 1990. La fouille d'un site acheuléen à Djita (basse vallée de la Falémé, Sénégal). L’Anthropologie, 94 (2), 293-304.

Collins, J.A., Govin, A., Mulitza, S., Heslop, D., Zabel, M., Hartmann, J., Röhl, U., Wefer, G., 2013. Abrupt shifts of the Sahara-Sahel boundary during Heinrich stadials. Climate of the Past, 9, 1181-1191.

Corbeil, R., Mauny, R., Charbonnier, J., 1948. Préhistoire et protohistoire de la presqu'île du Cap Vert et de l'extrême ouest sénégalais. Bulletin de l'Institut Français d'Afrique Noire, 10, 378-460.

Dagan, T., 1956.Le site préhistorique de Tiemassas (Sénégal). Bulletin de l’Institut français d'Afrique noire (B), 18 (3-4), 432-448.

Davies, O., 1964. The Lower and Middle Palaeolithic in West Africa. Rivista di Scienze preistoriche, 19 (1-4), 1-21. 
Descamps, C., Descamps, F., 2010. La Préhistoire au Sénégal. Nouvelles Éditions Africaines, Dakar.

De Weyer, L., 2008. Étude technologique de l'industrie lithique du Ménié-Ménié, Ounjougou, Mali. Master Dissertation, Université Paris X - Nanterre.

Guillot, R., Descamps, C., 1969. Nouvelles découvertes préhistoriques à Tiémassas (Sénégal). Bulletin de l'Institut français d'Afrique noire (B), 31, 602-637.

Garcea, E.A.A., 2012. Successes and failures of human dispersals from North Africa. Quaternary International, 270, 119-128.

Hajdas, I., 2008. Radiocarbon dating and its applications in Quaternary studies. Quaternary Science Journal - Eiszeitalter und Gegenwart, 57, 2-24.

Hugot, H.J., 1967. Le paléolithique terminal dans l'Afrique de l'Ouest. In: Bishop, W.W., Clark, J.D., Background to Evolution in Africa. University of Chicago Press, Chicago, pp. $529-555$.

Huysecom, E., 1987. Die archäologische Forschung in Westafrika. Beck, München.

Huysecom, E., 1990. Fanfannyégèné I. Steiner, Stuttgart.

Huysecom, E., Chevrier, B., Soriano, S., Rasse, M., Tribolo, C., in preparation. Between continuity and discontinuity: an overview of the West African Paleolithic over 200,000 years. Conference proceedings, 84th annual meeting of the American Association of Physical Anthropologists.

Huysecom, E., Jeanbourquin, C., Mayor, A., Chevrier, B., Loukou, S., Canetti, M., Diallo, M., Bocoum, H., Guèye, N.S., Hajdas, I., Lespez, L., Rasse, M., 2013. Reconnaissance dans la vallée de la Falémé (Sénégal oriental): la 15ème année de recherche du programme international «Peuplement humain et paléoenvironnement en Afrique de l'Ouest». In: Rapport annuel SLSA 2012. Zurich et Vaduz, Fondation Suisse-Liechtenstein pour les recherches archéologiques à l'étranger, pp. 25-112. 
Huysecom, E., Loukou, S., Mayor, A., Jeanbourquin, C., Chaix, L., Chevrier, B., Ballouche, A., Bocoum, H., Guèye, N.-S., Timpoko-Kiénon Kaboré, H., Rasse, M., Tribolo, C., 2014. Vallée de la Falémé (Sénégal Oriental) et Parc National des îles Eotilé (Côte d'Ivoire) : la 16ème année de recherche du programme«Peuplement humain et paléoenvironnement en Afrique ». In: Jahresbericht SLSA 2013.Zürich et Vaduz, Fondation Suisse-Liechtenstein pour les recherches archéologiques à l'étranger, pp. 113-176.

Huysecom, E., Mayor, A., Ozainne, S., Jeanbourquin, C., Loukou, S., Canetti, M., Ballouche, A., Cantin, N., Cissé, L., Eichhorn, B., Kahlheber, S., Rasse, M., Sanogo, K., 2012. Fouilles en Pays dogon et reconnaissance archéologique au Sénégal oriental: la 14ème année de recherches du programme «Peuplement humain et paléoenvironnement en Afrique de l'Ouest ». In: Jahresbericht SLSA2011. Zürich et Vaduz, Fondation Suisse-Liechtenstein pour les recherches archéologiques à l'étranger, pp. 99-172.

Huysecom, E., Ozainne, S., Mayor, A., Jeanbourquin, C., Robion-Brunner, C., Ballouche, B., Chaix, L., Cissé, L., Eichhorn, B., Garnier, A., Guindo, N., Kahlheber, S., Le Drézen, Y., Lespez, L., Loukou, S., Sanogo, K., Serneels, V., Soriano, S., Soulignac, R., Taibi, N., 2011. Le tell de Sadia en Pays dogon: la treizième année de recherches du programme «Peuplement humain et paléoenvironnement en Afrique de l'Ouest». In: Jahresbericht SLSA 2010. Zürich et Vaduz, Fondation Suisse-Liechtenstein pour les recherches archéologiques à l'étranger, pp. 101-221.

Laforgue, P., 1925.État actuel de nos connaissances sur la Préhistoire en A.O.F. Bulletin du comité d'études historiques et scientifiques de l'AOF, 8, 105-171.

Lebrun, B., Tribolo, C., Mercier, N., Camara, A., Chevrier, B., Lespez, L., Rasse, M., Huysecom, E., in preparation. West African chrono-cultural framework: first OSL dating of sedimentary formations in the Falémé Valley, eastern Senegal.

Lespez, L., Le Drézen, Y., Garnier, A., Rasse, M., Eichhorn, B., Ozainne, S., Ballouche, A., Neumann, K., Huysecom, E., 2011. High-Resolution Fluvial Records of Holocene Environmental Changes in the Sahel: the Yamé River at Ounjougou (Mali, West-Africa). Quaternary Science Reviews, 30 (5-6), 737-756. 
Lespez, L., Rasse, M., Le Drézen, Y., Tribolo, C., Huysecom, E., Ballouche, A., 2008.Signal climatique et hydrosystèmes continentaux entre 50 et 4 ka en Afrique de l'Ouest: l'exemple de la vallée du Yamé (Pays dogon, Mali). Géomorphologie, Relief, Processus, Environnement, 3, 169-186.

Lombard, M., 2012. Thinking through the Middle Stone Age of sub-Saharan Africa. Quaternary International, 270, 140-155.

Mauny, R., 1948. Pointe de flèche d'un type inusité trouvée près de Dakar. Bulletin de la Société Préhistorique Française, 45 (11-12), 405-406.

Mauny, R., 1963. Contribution à la préhistoire et à la protohistoire de la région de Kédougou (Sénégal Oriental). Bulletin de la Société Anthropologique de Paris, 1, 113-122.

McBrearty, S., Brooks, A., 2000. The revolution that wasn't: a new interpretation of the origin of modern human behavior. Journal of Human Evolution, 39, 453-563.

Michel, P., 1969. Les grandes étapes de la morphogenèse dans les bassins des fleuves Sénégal et Gambie pendant le Quaternaire. Bulletin de l'Institut français d'Afrique noire, 31 (2), 293324.

Michel, P., 1973. Les bassins des fleuves Sénégal et Gambie. Étude géomorphologique. Paris, Mémoire ORSTOM, 63.

Nyiang, K., Ndiaye, M., in press. The Middle Palaeolithic of West Africa: Lithic technotypological analyses of the site of Tiemassas, Senegal. Quaternary International.

Rasse, M., Soriano, S., Tribolo, C., Stokes, S., Huysecom, E., 2004. La séquence pléistocène supérieur d'Ounjougou (Pays Dogon, Mali): évolution géomorphologique, enregistrements sédimentaires et changements culturels. Quaternaire, 15 (4), 329-341. 
Rasse, M., Tribolo, C., Soriano, S., Huysecom, E., 2012. Premières données chronostratigraphiques sur les formations du Pléistocène supérieur de la "Falaise" de Bandiagara (Mali, Afrique de l'Ouest). Quaternaire, 23 (1), 3-21.

Richard, R., 1955. Contribution à l'étude de la stratigraphie du quaternaire de la Presqu'̂̂le du Cap-Vert (Sénégal). Bulletin de la Société Préhistorique Française, 52 (1-2), 80-88.

Richard, R., 1960. Hypothèses sur l'expansion et l'évolution des industries de style Sangoen et Kalinien dans l'Ouest Africain. Bulletin de la Société Préhistorique Française, 57, 95-104.

Robert, A., Soriano, S., Rasse, M., Stokes, S., Huysecom, E. 2003. First chrono-cultural reference framework for the West African Palaeolithic: new data from Ounjougou (Dogon Country, Mali). Journal of African Archaeology, 1, 151-169.

Scerri, E., Blinkhorn, J., Groucutt, H.S., Niang, K., in press. The Middle Stone Age of the Senegal River Valley. Quaternary International.

Soriano, S., 2003. Quand archaïque n'est pas ancien! Étude de cas dans le Paléolithique du Pays dogon (Ounjougou, Mali). Annales de la Fondation Fyssen, 18, 79-92.

Soriano, S., Rasse, M., Tribolo, C., Huysecom, E., 2010. Ounjougou: a long Middle Stone Age sequence in the Dogon country (Mali). In: Allsworth-Jones P. (Ed.), West African Archaeology. New developments, new perspectives. British Archaeological Reports International Series, 2164. Archaeopress, Oxford, pp. 1-14.

Tribolo, C., Rasse, M., Soriano, S., Huysecom, E., 2015. Defining a chronological framework for the Middle Stone Age in West Africa: Comparison of methods and models for OSL ages at Ounjougou (Mali). Quaternary Geochronology, 29, 80-96. 


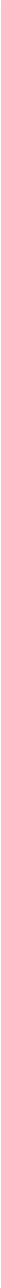




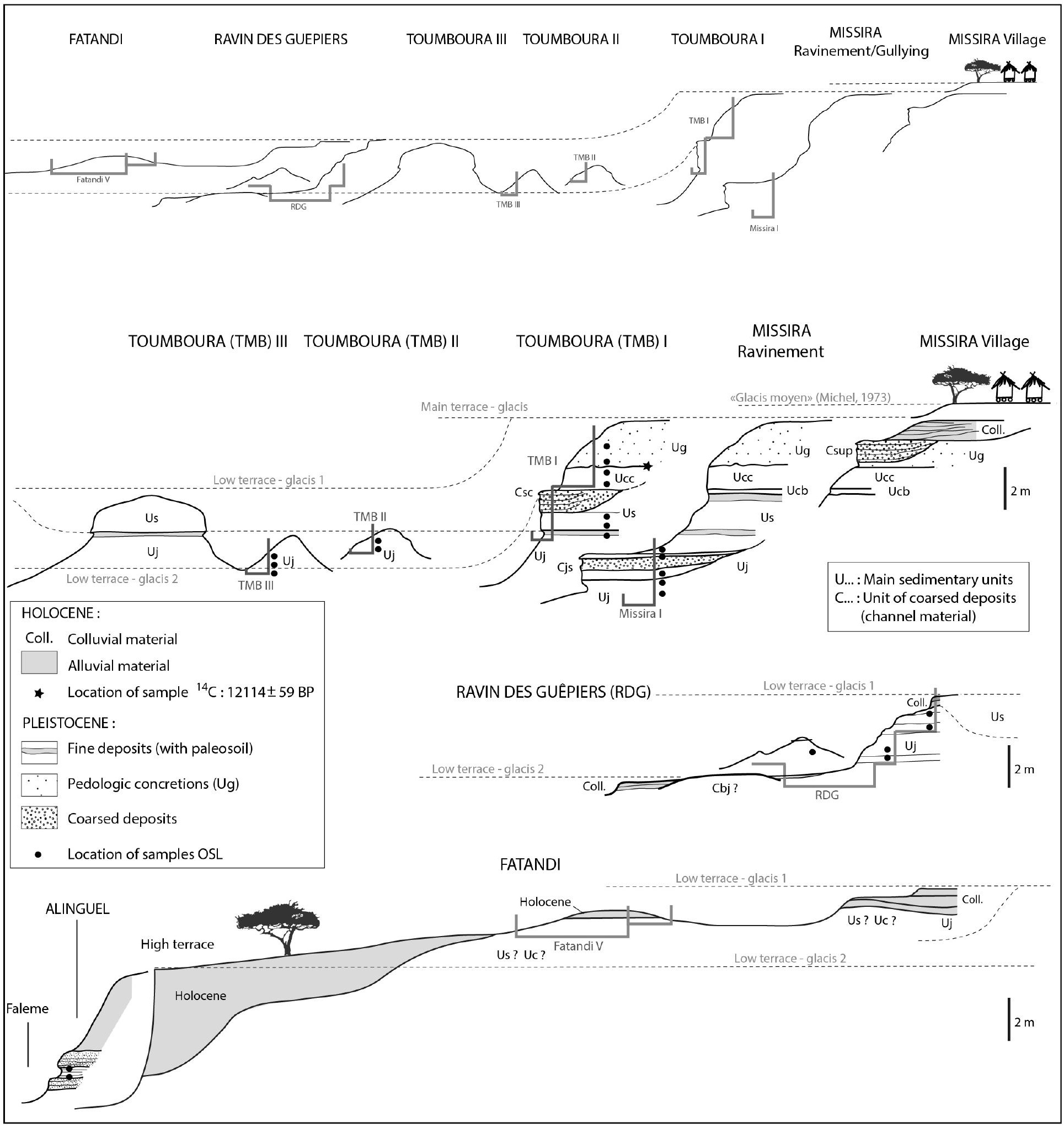




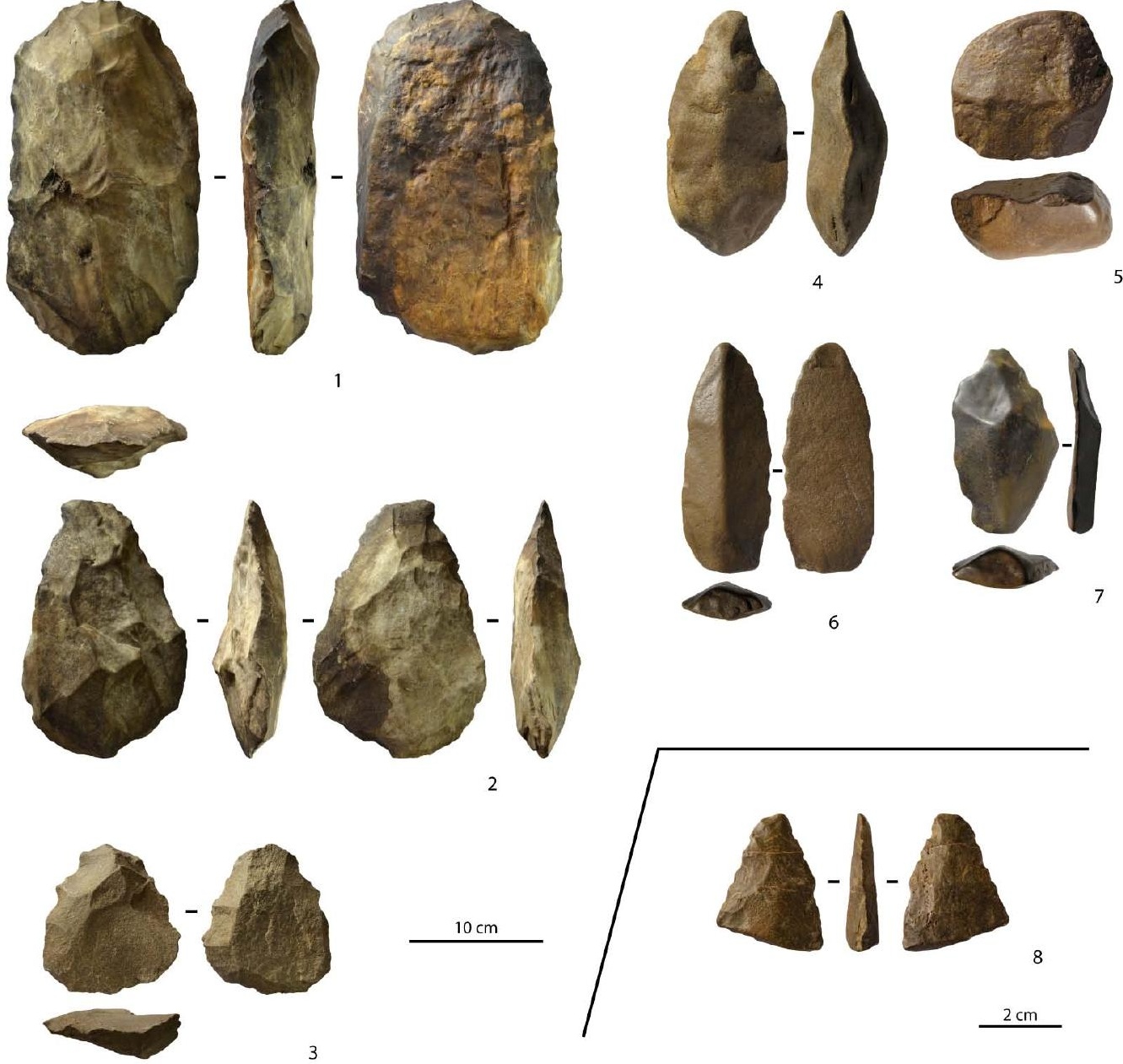


A
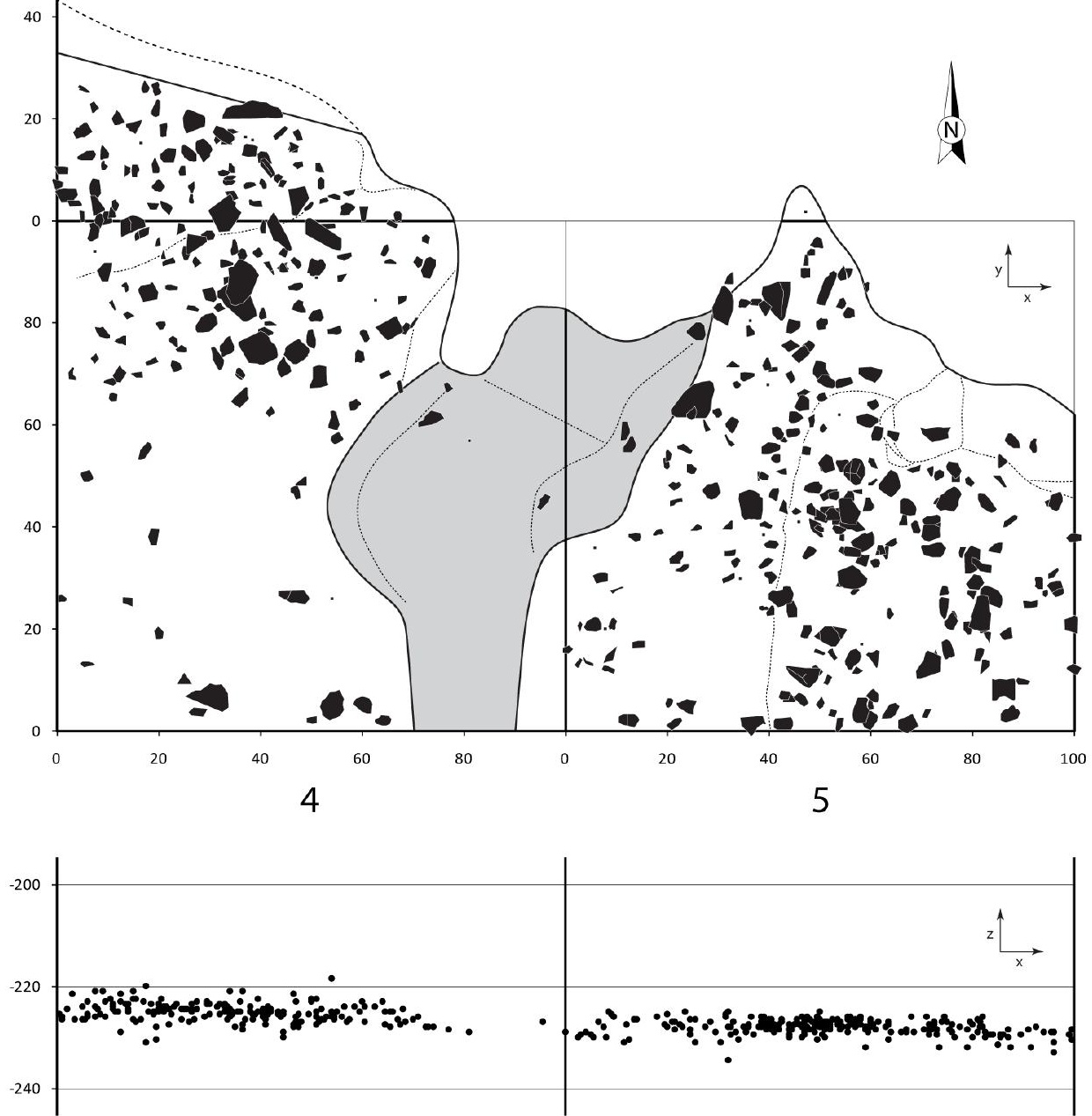

Toumboura II 2014 


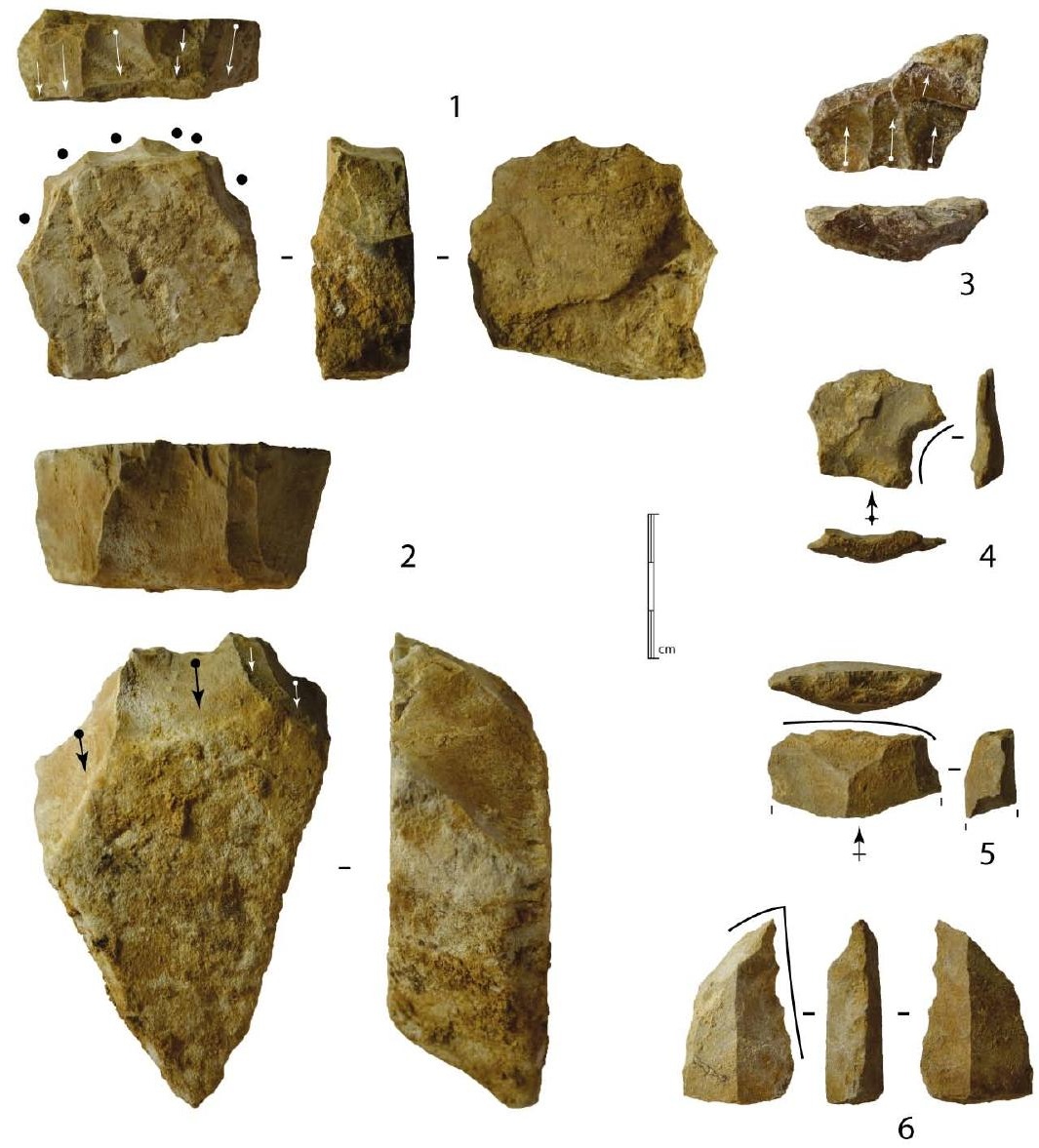




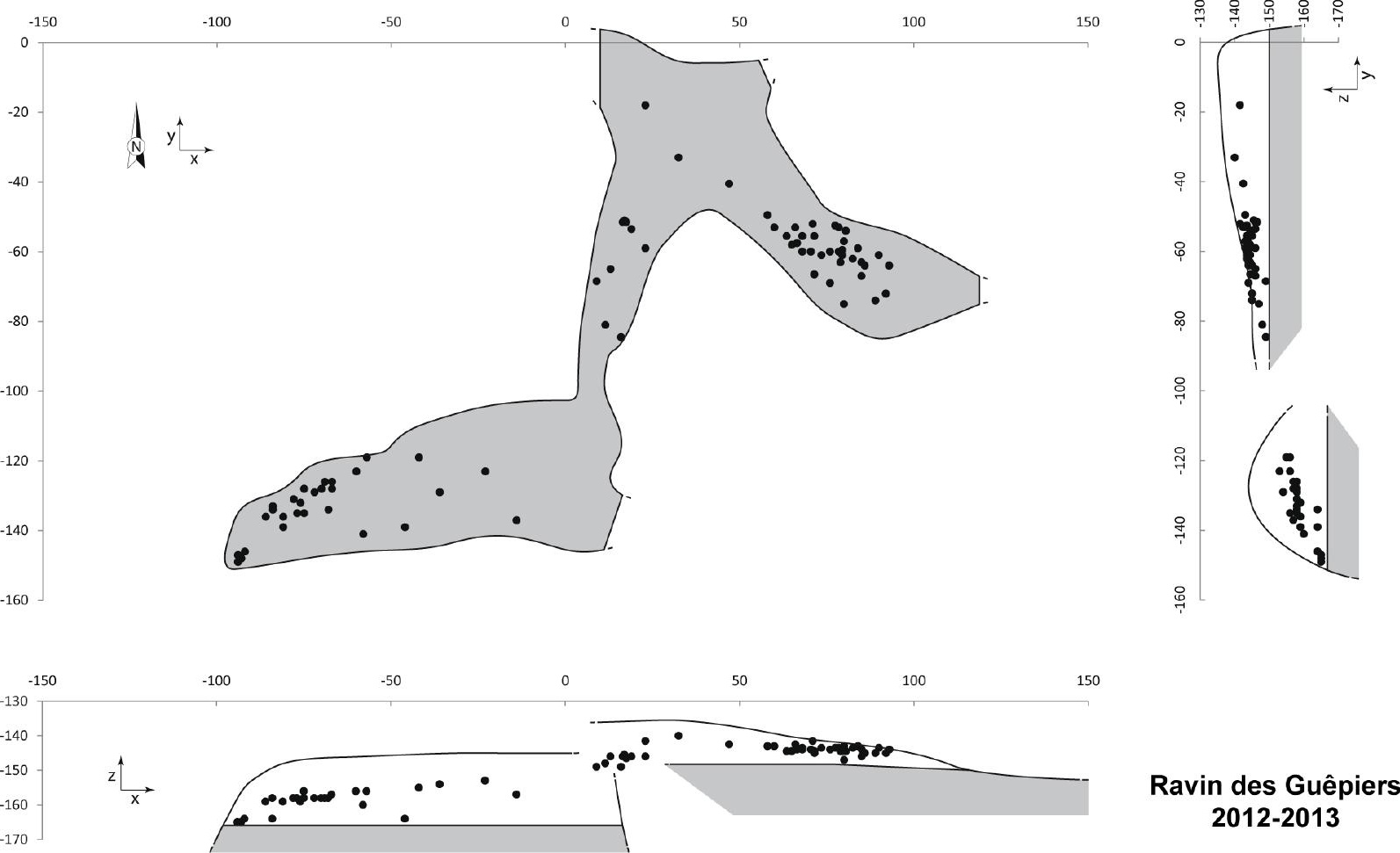



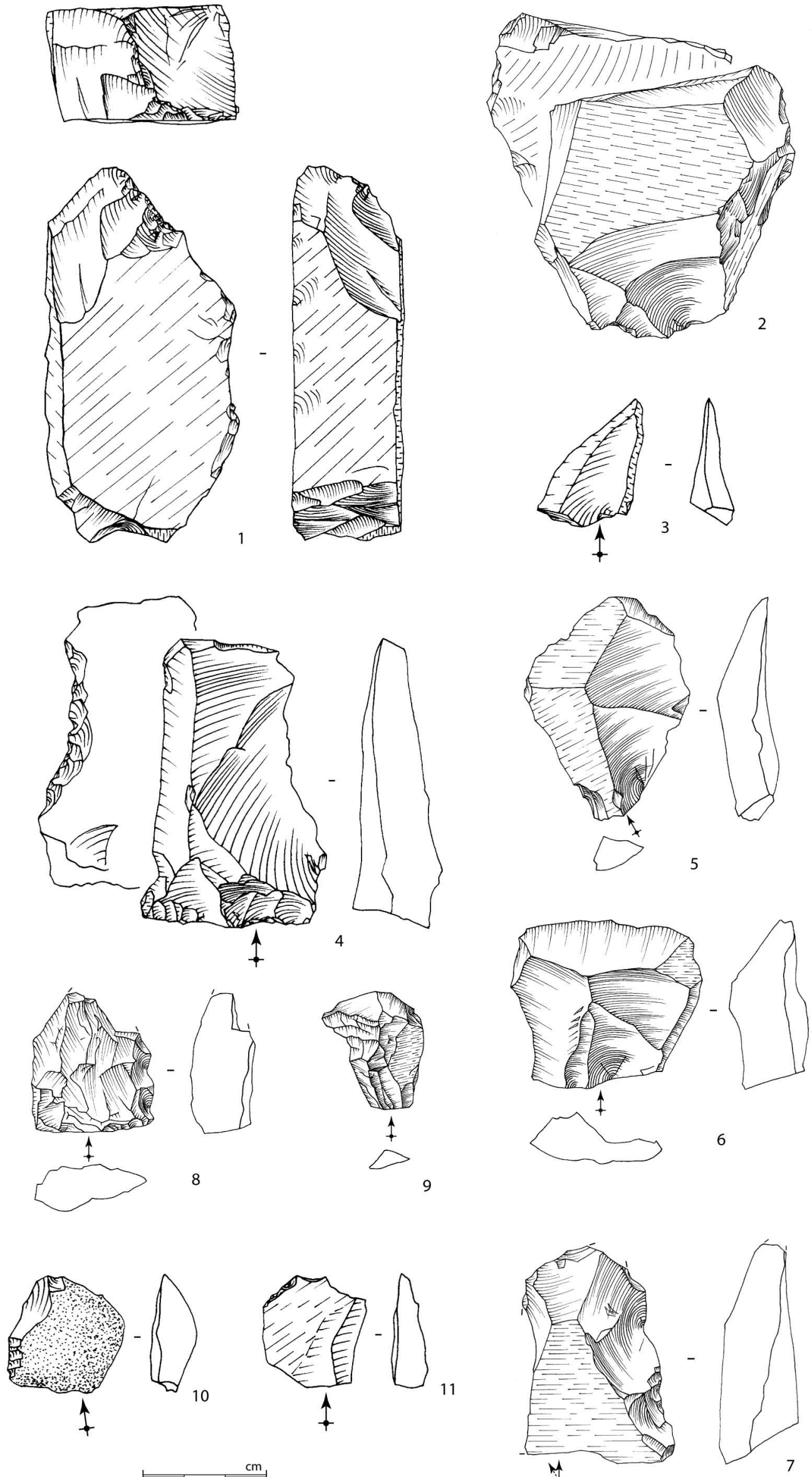


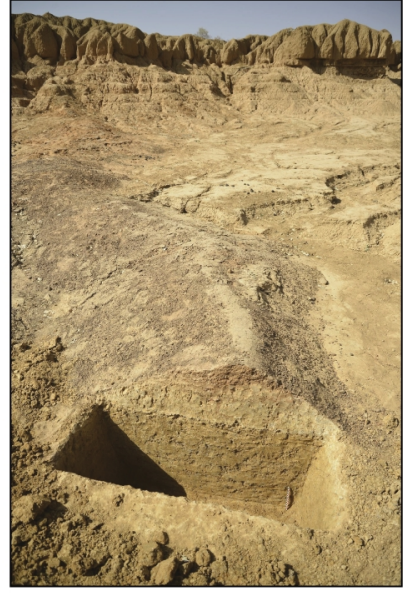

Test pit (base of Cjs and top of $\mathrm{Uj}$ )

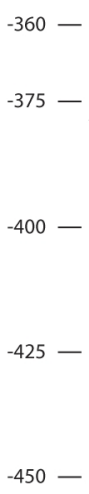

$-230-$

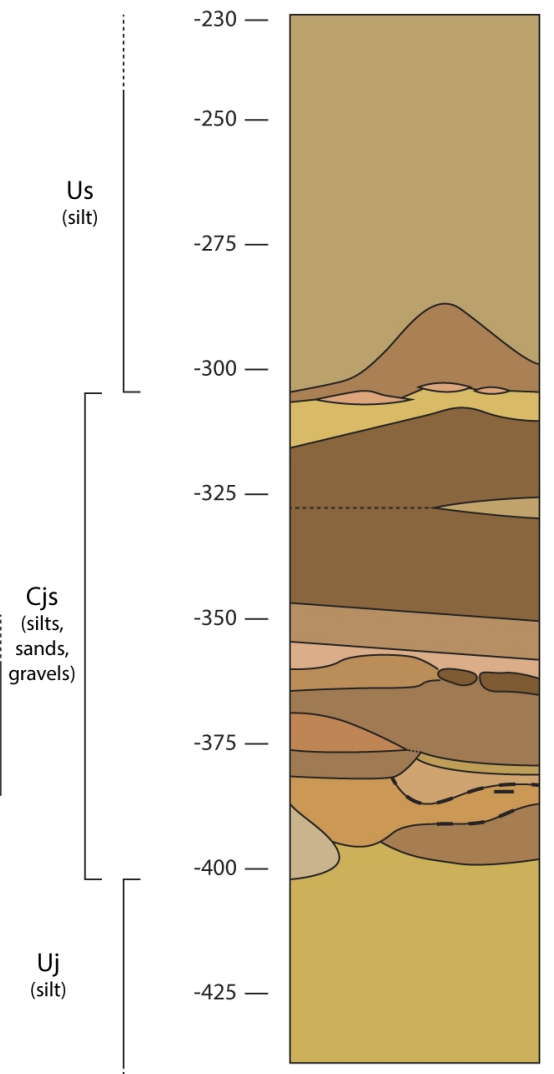

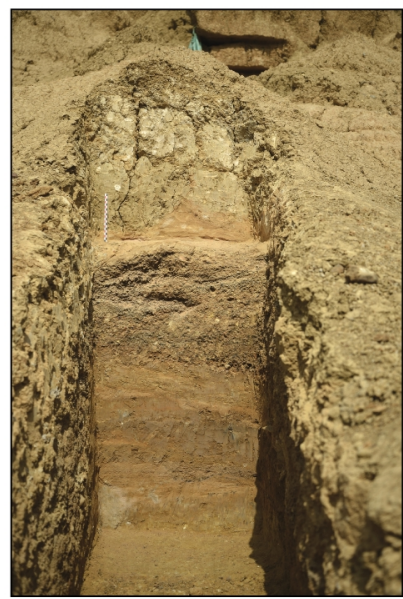

North section

(base of Us and top of Cjs) 


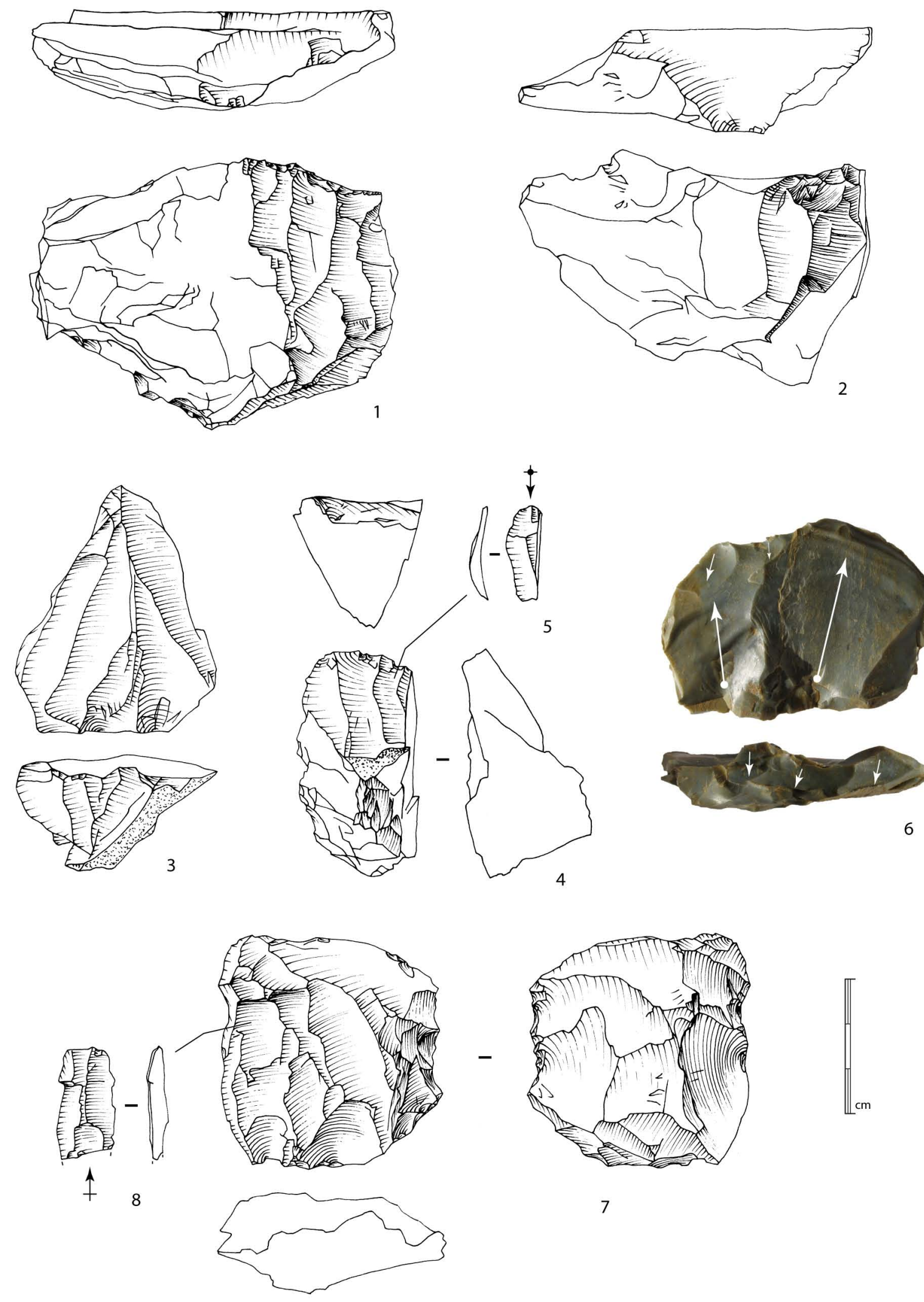

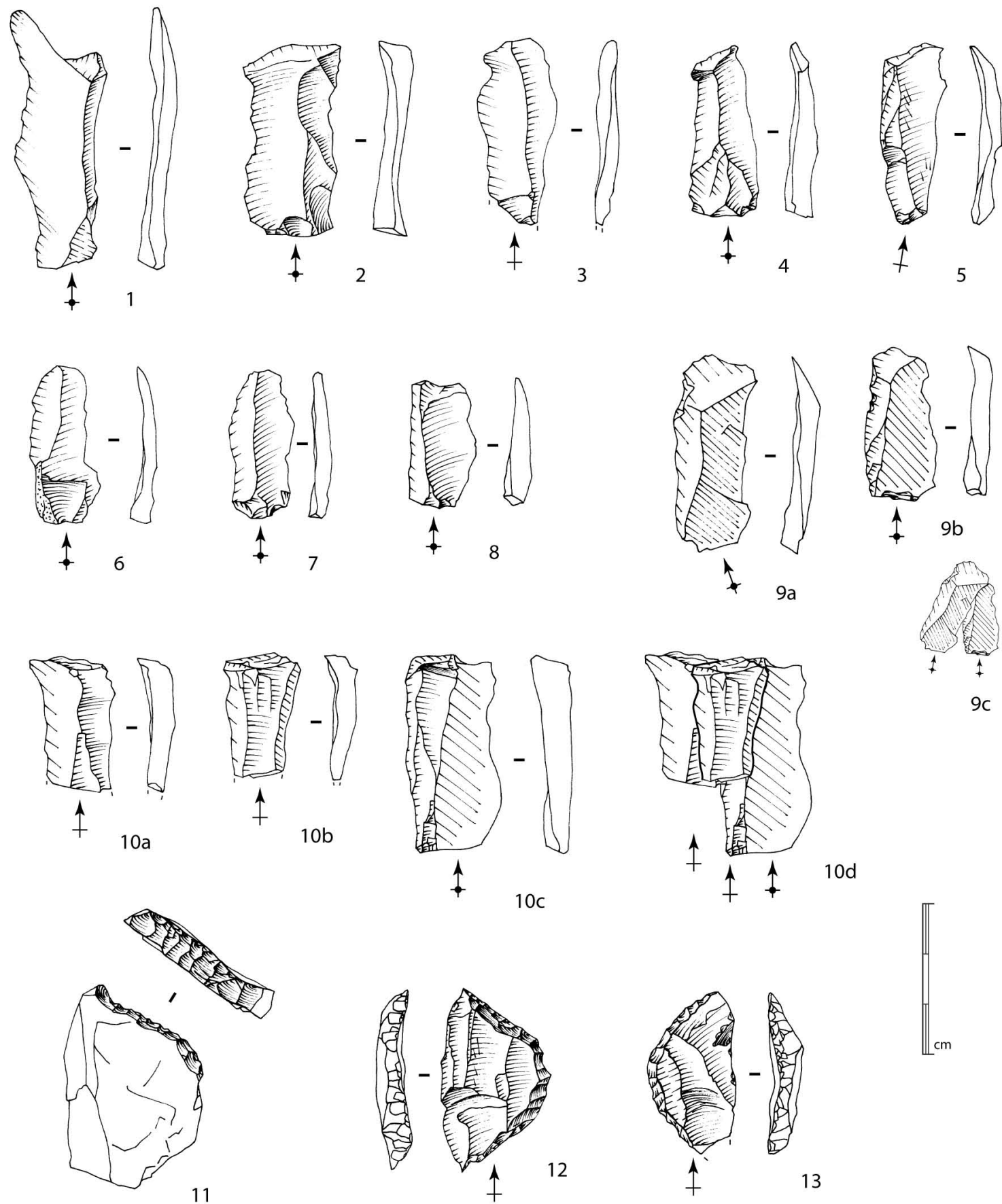

$\therefore$ E $E$

$\therefore$ EE E
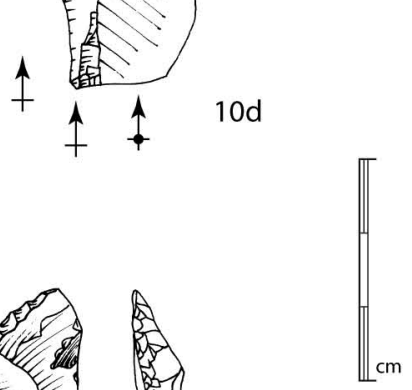

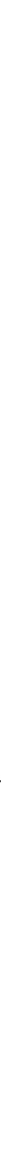


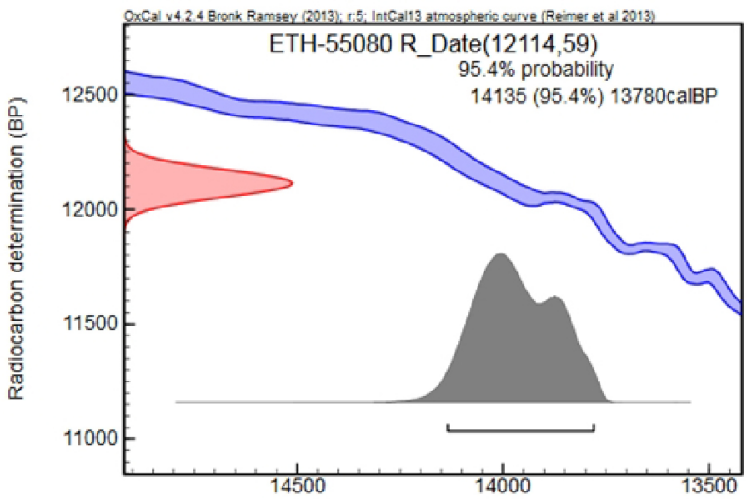

Calibrated date (calBP)

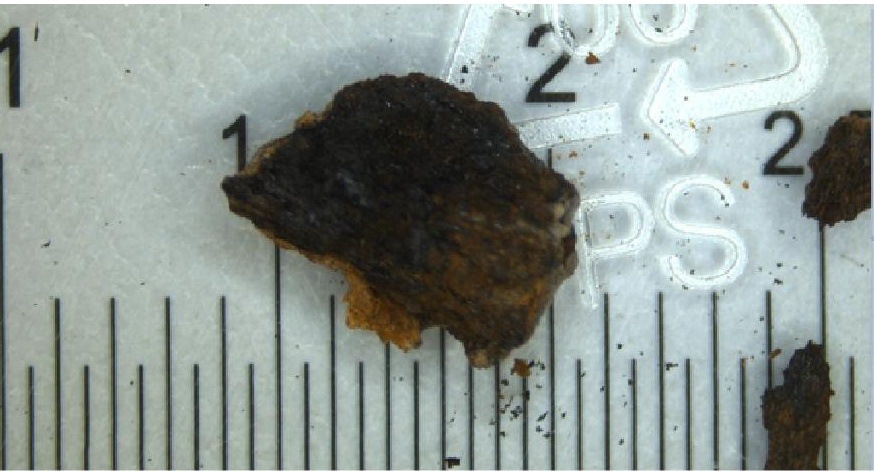


